\title{
Diagenesis of Clay Minerals in Sedimentary Basins
}

\author{
A Symposium \\ Third Goldschmidt Conference \\ Reston, Virginia \\ May 8-10, 1992
}

This symposium will bring together researchers who are using a variety of approaches - experimental, observational, and modeling - to investigate clay mineral reactions that occur during burial diagenesis. A focus of the session will be the problem that exists in relating laboratory and field determinations of the kinetics and thermodynamics of clays undergoing diagenesis.

Abstract Deadline December 16, 1991: Please send a copy to Kacandes

\section{Topics:}

Stability and solubility of clay minerals at intermediate temperatures

- Kinetics of clay mineral reactions

- Mechanisms of clay mineral transformation

- Interactions with organic acids

- Structure of diagenetic clays

- Phase relationships

- Relationship to geopressure development and maintenance

\section{Contacts:}

Symposium Conveners:
Virginia Colten-Bradley Division of Natural Science and Mathematics

St. Mary's College

St. Mary's City, MD 20686

(301) 862-0343

For Abstract Forms:

Donna Ricketts

Pennsylvania State Univ. 409 Keller Conference Ctr. University Park, PA 16802

(814) 863-1743 